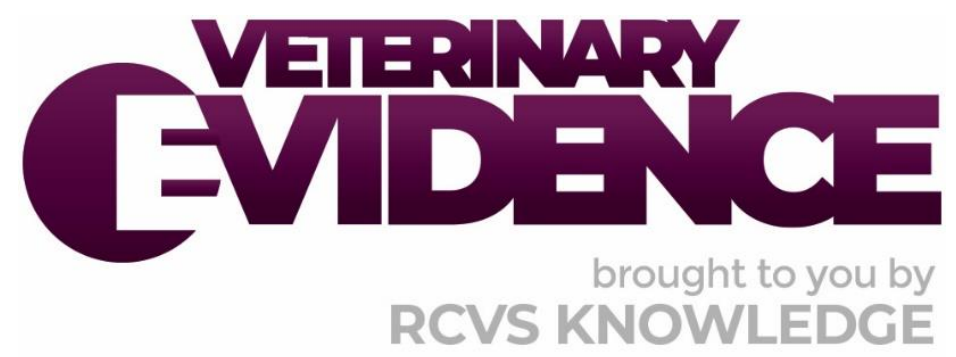

\title{
In horses undergoing volatile anaesthesia, does intraoperative alpha-2-agonist infusion improve recovery?
}

\section{A Knowledge Summary by}

\begin{abstract}
Alison Bennell BVMS CertAVP(EM) CertAVP(VA) MSc FHEA MRCVS ${ }^{{ }^{*}}$
${ }^{1}$ Institute of Veterinary Science, University of Liverpool, Chester High Road, Neston, CH64 7TE

*Corresponding Author (alison.bennell@liverpool.ac.uk)
\end{abstract}

ISSN: 2396-9776

Published: 17 Feb 2021

in: The Veterinary Evidence journal Vol 6, Issue 1

DOI: 10.18849/VE.V6I1.341

Reviewed by: Jackie Brearley (MA VetMB PhD MRCVS DVA

DipECVAA), John Hird (MA BVSc (Hons) DVA

DipECVAA MRCA MRCVS) and Kate Loomes

(BVSc(hons) MSc CertAVP(EP) CertAVP(VA)

Dip. ECVAA MRCVS)

Next Review Date: 30 Jan 2022 


\section{KNOWLEDGE SUMMARY}

\section{PICO question}

In horses undergoing volatile anaesthesia with isoflurane or sevoflurane, does administration of an alpha-2 agonist as a CRI compared to anaesthetic maintenance with volatile alone improve recovery quality?

\section{Clinical bottom line}

\section{Category of research question}

\section{Treatment}

\section{The number and type of study designs reviewed}

Eight papers were critically appraised. All prospective, randomised clinical trials. $7 / 8$ papers were blinded and $4 / 8$ were crossover design

\section{Strength of evidence}

\section{Moderate}

\section{Outcomes reported}

One paper investigating detomidine and one on romifidine showed no improvement in recovery quality. $3 / 3$ medetomidine papers and $2 / 3$ dexmedetomidine papers showed a significant improvement in recovery quality in the alpha-2 agonist CRI group

\section{Conclusion}

In a healthy horse undergoing general anaesthesia with isoflurane or sevoflurane maintenance, an intraoperative constant rate of infusion (CRI) of medetomidine and dexmedetomidine can lead to better recovery quality when compared to horses who are maintained on isoflurane or sevoflurane alone

\section{How to apply this evidence in practice}

The application of evidence into practice should take into account multiple factors, not limited to: individual clinical expertise, patient's circumstances and owners' values, country, location or clinic where you work, the individual case in front of you, the availability of therapies and resources.

Knowledge Summaries are a resource to help reinforce or inform decision making. They do not override the responsibility or judgement of the practitioner to do what is best for the animal in their care. 


\section{Clinical Scenario}

A 4-year-old Warmblood has presented for a bilateral stifle arthroscopy under general anaesthesia. After discussing the risks of general anaesthesia with the owner, they ask if there are any ways of making recovery safer. You decide to look up the evidence of giving an alpha-2 adrenoceptor agonist as a constant rate of infusion (CRI) intraoperatively and the effects on recovery from general anaesthesia.

\section{The evidence}

Although little evidence is available, there is high quality evidence in the form of prospective, randomised blinded studies to support the use of a CRI of an alpha-2 adrenoreceptor agonist intraoperatively to improve the quality of recovery in healthy horses undergoing volatile agent anaesthesia with isoflurane or sevoflurane. Crossover studies are less applicable to studies investigating anaesthetic recovery quality as recovery behaviour is learned and recoveries will improve with multiple general anaesthetics (Platt et al., 2017; and Valverde et al., 2013). Dexmedetomidine and medetomidine are the most investigated drugs in this class used in a partial intravenous anaesthesia (PIVA) protocol and the evidence shows that recovery quality is improved with the use of these drugs as a CRI when compared to volatile use alone. No adverse effects of using these drugs were observed in any of the studies and cardiorespiratory stability was maintained, which makes them valid choices to improve recovery.

\section{Summary of the evidence}

Creighton et al. (2012)

\begin{tabular}{|c|c|}
\hline Population: & $\begin{array}{l}\text { Healthy adult Standardbred research horses: } \\
\text { - } \quad \text { Age } 3-7 \text { years } \\
\text { - } \quad \text { Weight } 400-560 \mathrm{kgs} \\
\text { - } 150 \text { minutes anaesthesia time }\end{array}$ \\
\hline Sample size: & 10 horses \\
\hline Intervention details: & $\begin{array}{l}\text { Standard anaesthetic protocol (isoflurane maintenance) and either: } \\
\text { Group } 1(\mathrm{n}=10) \text { - Premedication of } 7 \mathrm{mcg} / \mathrm{kg} \text { medetomidine IV. } \\
\text { CRI of medetomidine at } 5 \mathrm{mcg} / \mathrm{kg} / \mathrm{hr} \\
\text { Group } 2(\mathrm{n}=10) \text { - Premedication with xylazine } 0.7 \mathrm{mg} / \mathrm{kg} \text { IV. No } \\
\text { CRI and } 0.2 \mathrm{mg} / \mathrm{kg} \text { xylazine IV at end of anaesthesia } \\
\text { Unassisted recovery from general anaesthesia } \\
\text { Crossover study and } 10 \text { day washout period }\end{array}$ \\
\hline Study design: & Prospective, blinded, randomised crossover study \\
\hline Outcome studied: & $\begin{array}{l}\text { - Subjective recovery score on 1-10 visual analogue scale } \\
\text { (VAS) and 11-100 behavioural recovery score (BRS) and } \\
\text { objective mean attempt interval (MAI) recovery scores by } \\
\text { two blinded anaesthetists } \\
\text { - Objective recovery time variables recorded for time until } \\
\text { extubation, time until first movement, time until sternal } \\
\text { recumbency and time until standing }\end{array}$ \\
\hline $\begin{array}{l}\text { Main findings: } \\
\text { (relevant to PICO question): }\end{array}$ & $\begin{array}{l}\text { - Time until extubation, first movement, time until standing } \\
\text { and number of attempts to stand were not statistically } \\
\text { different between the two groups } \\
\text { - Time to sternal recumbency was significantly longer in } \\
\text { Group } 1(p=0.019) \\
\text { - MAI ( } p=0.025) \text { and VAS ( } p=0.047) \text { significantly better with } \\
\text { Group } 1 \\
\text { BRS was better with Group } 1 \text {, but no statistical difference }\end{array}$ \\
\hline
\end{tabular}




\begin{tabular}{|l|l|}
\hline Limitations: & $\begin{array}{l}\text { - Small sample number } \\
\text { - Only two blinded observers }\end{array}$ \\
& $\begin{array}{l}\text { - Crossover design may influence results as horses have been } \\
\text { shown to have improved recoveries after multiple }\end{array}$ \\
& anaesthetics \\
& $\begin{array}{l}\text { No surgery was performed, so it is difficult to extrapolate to } \\
\text { clinical practice }\end{array}$ \\
\hline
\end{tabular}

\begin{tabular}{|c|c|}
\hline \multicolumn{2}{|l|}{ Devisscher et al. (2010) } \\
\hline Population: & $\begin{array}{l}\text { Horses undergoing routine arthroscopy: } \\
\text { - American Society of Anesthesiologists (ASA) category I or II } \\
\text { - Age 3-6 years } \\
\text { - Weight } 339-627 \mathrm{kgs} \\
\text { - } 116 \pm 33 \text { minutes anaesthesia time }\end{array}$ \\
\hline Sample size: & 30 horses \\
\hline Intervention details: & $\begin{array}{l}\text { Standard anaesthetic protocol (isoflurane maintenance) with } \\
\text { premedication of romifidine at } 80 \mathrm{mcg} / \mathrm{kg} \text { IV then divided into two } \\
\text { groups: } \\
\quad \text { Group } 1(\mathrm{n}=15) \text { - Romifidine CRI at } 40 \mathrm{mcg} / \mathrm{kg} / \mathrm{hr} \\
\text { Group } 2(\mathrm{n}=15) \text { - Saline placebo CRI } \\
\text { All horses given } 20 \mathrm{mcg} / \mathrm{kg} \text { romifidine IV for recovery (before } \\
\text { transport to recovery box) } \\
\text { Unassisted recovery from general anaesthesia }\end{array}$ \\
\hline Study design: & Randomised, blinded, prospective clinical trial \\
\hline Outcome studied: & $\begin{array}{l}\text { - Subjective assessment of recovery quality score (1-5) using } \\
\text { a previously described scoring system (Gozalo-Marcilla et al., } \\
\text { 2010) } \\
\text { - Objective measurement of time until extubation, time to } \\
\text { - } \text { sternal recumbency and time until standing were recorded } \\
\text { - Paper does not specify who scored recovery }\end{array}$ \\
\hline $\begin{array}{l}\text { Main findings: } \\
\text { (relevant to PICO question): }\end{array}$ & $\begin{array}{l}\text { - Quality of recovery did not significantly differ between } \\
\text { groups ( } p=0.109) \\
\text { - More horses in Group } 1 \text { stood at the first attempt (it is } \\
\text { unclear how many horses this applied to) } \\
\text { - Recovery times did not differ between the two groups }\end{array}$ \\
\hline Limitations: & $\begin{array}{l}\text { - Subjective recovery quality scores } \\
\text { - The method of blinding and scored recoveries was not } \\
\text { explained clearly } \\
\text { - All horses were sedated for recovery, which may have } \\
\text { influenced recovery quality significantly }\end{array}$ \\
\hline
\end{tabular}




\begin{tabular}{|c|c|}
\hline \multicolumn{2}{|l|}{ Gozalo-Marcilla et al. (2013) } \\
\hline Population: & $\begin{array}{l}\text { Healthy research ponies: } \\
\text { - Age } 12.7 \pm 2.8 \text { years } \\
\text { - Weight } 294 \pm 51 \text { kgs } \\
\text { - } 146-362 \text { minutes anaesthesia time }\end{array}$ \\
\hline Sample size: & Six ponies \\
\hline Intervention details: & $\begin{array}{l}\text { Standard anaesthetic protocol (sevoflurane induction and } \\
\text { maintenance) then ponies divided into two groups: } \\
\text { Group } 1(\mathrm{n}=6)-\text { Dexmedetomidine bolus at } 3.5 \mathrm{mcg} / \mathrm{kg} \text { IV then } \\
\text { CRI at } 1.75 \mathrm{mcg} / \mathrm{kg} / \mathrm{hour} \\
\text { Group } 2(\mathrm{n}=6)-\text { Sevoflurane only with saline placebo (volume } \\
\text { equivalent to other group) } \\
\text { All ponies given } 0.875 \mathrm{mcg} / \mathrm{kg} \text { medetomidine IV for recovery and } \\
\text { assisted with manual tail support } \\
\text { Crossover study and } 3 \text { week washout period }\end{array}$ \\
\hline Study design: & Blinded, prospective, randomised, crossover experimental study \\
\hline Outcome studied: & $\begin{array}{l}\text { - Subjective assessment of recovery quality score }(1-5) \text { using } \\
\text { a previously described scoring system (Gozalo-Marcilla et al., } \\
\text { 2010) } \\
\text { - Scored by one blinded anaesthetist } \\
\text { - Objective time variables recorded: time to extubation, time } \\
\text { until sternal recumbency and time until standing }\end{array}$ \\
\hline $\begin{array}{l}\text { Main findings: } \\
\text { (relevant to PICO question): }\end{array}$ & $\begin{array}{l}\text { - There was no difference in recovery scores between the two } \\
\text { groups } \\
\text { - Objective time variables were not different between the two } \\
\text { groups }\end{array}$ \\
\hline Limitations: & $\begin{array}{l}\text { - Small sample number } \\
\text { - } \quad \text { Only one blinded observer } \\
\text { - } \text { where they were anaesthetised, which may influence results } \\
\text { as horses have been shown to have improved recoveries } \\
\text { after multiple anaesthetics } \\
\text { - Small horses may not be representative of horse population } \\
\text { - No surgery was performed, so it is difficult to extrapolate to } \\
\text { clinical practice } \\
\text { - Ponies were manually assisted in recovery, which may not } \\
\text { be applicable to many clinical situations }\end{array}$ \\
\hline
\end{tabular}

Marcilla et al. (2012)

Population: Client-owned horses:

- ASA I or II

- Age 7 months-16 years

- Weight $491 \pm 102 \mathrm{kgs}$

- undergoing elective orthopaedic or soft tissue surgery $>60$ minutes duration 


\begin{tabular}{|c|c|}
\hline Sample size: & 40 horses \\
\hline Intervention details: & $\begin{array}{l}\text { Standard anaesthetic protocol (isoflurane maintenance) with } \\
\text { premedication of dexmedetomidine at } 3.5 \mathrm{mcg} / \mathrm{kg} \text { IV then horses } \\
\text { divided into two groups: } \\
\text { Group } 1(\mathrm{n}=20)-\mathrm{CRI} \text { dexmedetomidine } 1.75 \mathrm{mcg} / \mathrm{kg} / \mathrm{hr} \\
\text { Group } 2(\mathrm{n}=20)-\text { Saline CRI (equivalent volume to other group) } \\
\text { All sedated with } 0.875 \mathrm{mcg} / \mathrm{kg} \text { dexmedetomidine for recovery. } \\
\text { Unassisted recoveries performed }\end{array}$ \\
\hline Study design: & Prospective, randomised, blinded clinical study \\
\hline Outcome studied: & $\begin{array}{l}\text { - Subjective assessment of recovery quality score (1-5) using } \\
\text { a previously described scoring system (Gozalo-Marcilla et al., } \\
\text { 2010) by one blinded observer } \\
\text { - Objective measurement of time until extubation, time to } \\
\text { sternal recumbency, time until standing were recorded }\end{array}$ \\
\hline $\begin{array}{l}\text { Main findings: } \\
\text { (relevant to PICO question): }\end{array}$ & $\begin{array}{l}\text { - Recovery scores better in Group } 1(p=0.03) \text { compared with } \\
\text { Group } 2 \\
\text { - Group } 1 \text { took fewer attempts to stand }(p=0.04) \\
\text { - First attempts to stand were significantly longer in Group } 1 \\
(p=0.04) \text { compared to Group } 2\end{array}$ \\
\hline Limitations: & $\begin{array}{l}\text { - } \quad \text { Subjective recovery score } \\
\text { - } \quad \text { Recoveries scored by one blinded observer } \\
\text { influenced recovery quality significantly } \\
\text { - Different premedicant doses were used in different horses } \\
\text { due to the varying temperament of horses }\end{array}$ \\
\hline
\end{tabular}

\begin{tabular}{|c|c|}
\hline \\
\hline \multicolumn{2}{|l|}{$\begin{array}{l}\text { Risberg et al. (2016) } \\
\text { Population: }\end{array}$} \\
\hline $\begin{array}{l}\text { Risberg et al. (2016) } \\
\qquad \text { Population: } \\
\text { Sample size: }\end{array}$ & \multirow[b]{2}{*}{$\begin{array}{l}\text { Eight horses } \\
\text { Standard anaesthetic protocol (isoflurane maintenance) with a } \\
\text { premedication of } 8 \mathrm{mcg} / \mathrm{kg} \text { dexmedetomidine then divided into two } \\
\text { groups: } \\
\quad \text { Group } 1(\mathrm{n}=8)-1.75 \mathrm{mcg} / \mathrm{kg} / \mathrm{hr} \text { dexmedetomidine CRI } \\
\quad \text { Group } 2(\mathrm{n}=8)-\text { Saline CRI (equivalent volume to other group) } \\
\text { Crossover study and minimum washout period of } 10 \text { days }\end{array}$} \\
\hline \multirow{3}{*}{$\begin{array}{r}\text { Intervention details: } \\
\text { Study design: } \\
\text { Outcome studied: } \\
\end{array}$} & \\
\hline & Sequential, blinded, randomised, balanced, crossover study \\
\hline & $\begin{array}{l}\text { - Subjective recovery score on 1-100 VAS by one blinded } \\
\text { anaesthetist } \\
\text { - Objective recovery time variables recorded were time to } \\
\text { sternal recumbency, number of attempts to stand and total } \\
\text { time until standing }\end{array}$ \\
\hline
\end{tabular}




\begin{tabular}{|c|c|}
\hline $\begin{array}{l}\text { Main findings: } \\
\text { (relevant to PICO question): }\end{array}$ & $\begin{array}{l}\text { - Recovery times did not significantly differ between groups } \\
\text { - Recovery scores were better with dexmedetomidine than } \\
\text { saline }(p=0.023) \\
\text { - All horses in Group } 1 \text { stood on the first attempt, horses in } \\
\text { Group } 2 \text { made a median of three attempts to stand }\end{array}$ \\
\hline Limitations: & $\begin{array}{l}\text { - Small sample size } \\
\text { - Subjective recovery quality score } \\
\text { - } \quad \text { Only one observer scored recoveries } \\
\text { - } \text { clinical practice } \\
\text { - Crossover design may influence results as horses have been } \\
\text { shown to have improved recoveries after multiple } \\
\text { anaesthetics }\end{array}$ \\
\hline
\end{tabular}

Schauvliege et al. (2011)

\begin{tabular}{|c|c|}
\hline Population: & $\begin{array}{l}\text { Healthy client-owned horses undergoing elective soft tissue and } \\
\text { orthopaedic surgery: } \\
\text { - ASA I or II } \\
\text { - Age 1.5-9 years } \\
\text { - Weight } 325-672 \mathrm{kgs} \\
\text { - } 45-90 \text { minutes anaesthesia time }\end{array}$ \\
\hline Sample size: & 20 horses \\
\hline Intervention details: & $\begin{array}{l}\text { Standard anaesthetic protocol (isoflurane maintenance) with } \\
\text { premedication of detomidine at } 10 \mathrm{mcg} / \mathrm{kg} \text { then divided into two } \\
\text { groups: } \\
\quad \text { Group } 1(\mathrm{n}=10)-\mathrm{CRI} \text { of detomidine at } 5 \mathrm{mcg} / \mathrm{kg} / \mathrm{hr} \\
\text { Group } 2(\mathrm{n}=10)-\text { Saline CRI (equivalent volume to other group) } \\
\text { All sedated with } 0.25 \mathrm{mcg} / \mathrm{kg} \text { detomidine IV for recovery } \\
\text { Unassisted recoveries performed }\end{array}$ \\
\hline Study design: & Prospective, randomised, blinded clinical trial \\
\hline Outcome studied: & $\begin{array}{l}\text { - Subjective assessment of recovery using a 1-6 point } \\
\text { recovery scoring system by the blinded anaesthetist who } \\
\text { performed the general anaesthetic } \\
\text { - Objective time variables of time to extubation, time to } \\
\text { sternal recumbency, time until standing were recorded }\end{array}$ \\
\hline $\begin{array}{l}\text { Main findings: } \\
\text { (relevant to PICO question): }\end{array}$ & $\begin{array}{l}\text { - Recovery scores were not statistically different between the } \\
\text { two groups } \\
\text { - Objective time variables were not statistically different } \\
\text { between the two groups }\end{array}$ \\
\hline Limitations: & $\begin{array}{l}\text { - Non-validated subjective recovery score } \\
\text { - Only one, unblinded observer which can introduce } \\
\text { - Significant bias } \\
\text { - } \quad \text { All horses were sedated for recovery, which may have } \\
\text { influenced recovery quality significantly }\end{array}$ \\
\hline
\end{tabular}




\begin{tabular}{|c|c|}
\hline \multicolumn{2}{|l|}{ Simeonova et al. (2017) } \\
\hline Population: & $\begin{array}{l}\text { Healthy research horses: } \\
\text { - Age } 4-20 \text { years } \\
\text { - Weight } 272 \pm 27 \mathrm{kgs} \\
\text { - } 3 \text { hours anaesthesia time }\end{array}$ \\
\hline Sample size: & Six horses \\
\hline Intervention details: & $\begin{array}{l}\text { Standard anaesthetic protocol (sevoflurane maintenance) with } \\
\text { premedication of } 0.8 \mathrm{mg} / \mathrm{kg} \text { xylazine then divided into two groups: } \\
\text { Group } 1(\mathrm{n}=6)-1.75 \mathrm{mcg} / \mathrm{kg} / \mathrm{hr} \text { medetomidine } \mathrm{CRI} \\
\text { Group } 2(\mathrm{n}=6)-\text { Saline CRI (equivalent volume to other group) } \\
\text { Unassisted recovery from general anaesthesia } \\
\text { Crossover study with } 2 \text { week washout period }\end{array}$ \\
\hline Study design: & Prospective, randomised, crossover study \\
\hline Outcome studied: & $\begin{array}{l}\text { - Subjective assessment of recovery quality score (1-5) using } \\
\text { a previously described scoring system (Gozalo-Marcilla et al., } \\
\text { 2010) } \\
\text { - Objective timings from end of anaesthesia until sternal } \\
\text { recumbency and standing }\end{array}$ \\
\hline $\begin{array}{l}\text { Main findings: } \\
\text { (relevant to PICO question): }\end{array}$ & $\begin{array}{l}\text { - Timings to extubation, sternal recumbency and standing } \\
\text { were similar between the groups } \\
\text { - Group } 1 \text { had better recoveries than Group } 2(p<0.05)\end{array}$ \\
\hline Limitations: & $\begin{array}{l}\text { - Small sample number } \\
\text { - } \quad \text { Crot blinded } \\
\text { shown to have improved recoveries after multiple } \\
\text { anaesthetics } \\
\text { - Small horses may not be representative of horse population } \\
\text { - Unsure who scored recoveries } \\
\text { - No surgery was performed, so it is difficult to extrapolate to } \\
\text { clinical practice }\end{array}$ \\
\hline
\end{tabular}

\begin{tabular}{|c|c|}
\hline Population: & $\begin{array}{l}\text { Thoroughbred racehorses undergoing arthroscopy: } \\
\text { - Age } 3.7 \pm 1 \text { years } \\
\text { - Weight } 456 \pm 34 \text { kgs }\end{array}$ \\
\hline Sample size: & 50 horses \\
\hline Intervention details: & $\begin{array}{l}\text { Standard anaesthetic protocol (sevoflurane maintenance) with } \\
\text { premedication of } 5 \mathrm{mcg} / \mathrm{kg} \text { medetomidine then horses divided into } \\
\text { two groups: } \\
\text { Group } 1(\mathrm{n}=25) \text { - Medetomidine CRI at } 3 \mathrm{mcg} / \mathrm{kg} / \mathrm{hr} \text { and no } \\
\text { sedation for recovery } \\
\text { Group } 2(\mathrm{n}=25) \text { - Sevoflurane maintenance only, } 1 \mathrm{mcg} / \mathrm{kg} \\
\text { medetomidine for recovery } \\
\text { Unassisted recoveries from anaesthesia }\end{array}$ \\
\hline Study design: & Blinded, prospective, randomised clinical study \\
\hline
\end{tabular}




\begin{tabular}{|c|c|}
\hline Outcome studied: & $\begin{array}{l}\text { - Subjective assessment of recovery quality score (1-5) using } \\
\text { a previously described scoring system (Gozalo-Marcilla et al., } \\
\text { 2010) by two blinded observers } \\
\text { Objective time variables recorded: time to extubation, first } \\
\text { movement, time until sternal recumbency, time until first } \\
\text { attempt to stand, number of attempts to stand and time } \\
\text { until standing }\end{array}$ \\
\hline $\begin{array}{l}\text { Main findings: } \\
\text { (relevant to PICO question): }\end{array}$ & $\begin{array}{l}\text { - Number of attempts to stand was fewer in Group } 1 \\
(p=0.003) \\
\text { - Recovery score was significantly better in Group } 1(p=0.014) \\
\text { - Objective time variables were not different between the two } \\
\text { groups }\end{array}$ \\
\hline Limitations: & $\begin{array}{l}\text { - Subjective recovery quality scoring system } \\
\text { - The sevoflurane only group received additional sedation for } \\
\text { recovery which may have influenced outcome } \\
\text { - Medetomidine can provide analgesia, which may influence } \\
\text { recovery from anaesthesia } \\
\text { - Only two blinded observers }\end{array}$ \\
\hline
\end{tabular}

\section{Appraisal, application and reflection}

Equine anaesthesia is high risk, with a mortality rate of approximately $0.12-1 \%$ in healthy horses undergoing elective surgery (Bidwell et al., 2007; and Johnston et al., 2002). Recovery is one of the highest risk periods as catastrophic injury can occur, such as limb fractures or subluxations, accounting for $71.4 \%$ of fatal recovery complications (Dugdale et al., 2016). A good quality of recovery plays a major part in the outcome of anaesthesia and surgery, and although many variables such as age, duration of anaesthesia, bodyweight, time of surgery and ASA physical status may influence recovery (Dugdale et al., 2016), any anaesthetic protocol which is proven to improve recovery quality should be considered. The aim of partial intravenous anaesthesia (PIVA) is to reap the multiple benefits of the minimum alveolar concentration (MAC)-sparing effects (Ringer et al., 2007), due to additional analgesia so a less volatile agent is required to maintain a suitable plane of anaesthesia. Benefits of PIVA include reduced cardiovascular depression, as lower doses of commonly used inhalational agents are required, and it may also provide a positive influence on recoveries, leading to a smoother and more controlled recovery period. Although many drugs, such as lidocaine, ketamine and opioids can also be used in PIVA protocols, alpha-2 agonists may provide additional benefits in terms of recovery quality due to their mental-calming effects.

Recovery quality encompasses several factors. These factors include successfully recovering and standing after anaesthesia without injury, how calm the horse is during recovery, how ataxic the horse is during and immediately after standing, the number of attempts to stand and the time taken until standing after the cessation of anaesthesia.

A recovery of good quality will be uneventful and controlled, the horse stands successfully with no injury, return to consciousness is smooth (so no emergence delirium occurs), transitions from lateral recumbency to sternal recumbency to standing are smooth, horses stand after one or two attempts as they have adequate musculoskeletal strength and coordination and they remain standing with minimal or no ataxia being present. This then ranges through to poor recoveries where horses can thrash around, injury is sustained (which can range from a skin abrasion through to a fatal catastrophic injury), the horse falls after standing or is severely ataxic, there are multiple attempts to stand or the horse fails to stand after anaesthesia. The most commonly used recovery scoring system in the appraised papers is described by Gozalo-Marcilla et al. (2010), which is based on an original paper by Young \& Taylor (1993). Vettorato et al. (2010) validated four different recovery scoring systems and found them all to be adequately reliable. 
Eight relevant papers were found which investigated the effects of CRIs of alpha-2 agonists on recovery in horses to answer the PICO question. They are all prospective, randomised studies with varying degrees of blinding. Most involve client-owned horses undergoing elective anaesthesia, but there is also evidence from research horses undergoing research anaesthesia, mainly for cardiorespiratory studies.

There is little published evidence directly comparing recovery in horses undergoing volatile agent anaesthesia only and those receiving a CRI of alpha-2 agonists, without sedation in recovery for either or both groups. Papers have also been published comparing recovery after an alpha-2 agonist CRI where additional CRIs, such as ketamine or lidocaine, have also been used in both study groups (Kempchen et al., 2012; Sacks et al., 2017; and Valverde et al., 2010). In examining the evidence for the PICO question, the assessment of the influence of the CRIs on recovery quality will likely be complicated by the administration of further sedation in recovery. Performing studies without further sedation for recovery can be challenging as in many centres horses need to be transported to recovery boxes, so further sedation is given for safety reasons, to try to prevent a premature recovery. A bolus of sedation has been shown to improve recoveries (Santos et al., 2003), however many patient factors, clinical factors and individual preference helps guide decision making as there is little evidence in this area.

There are several limitations to the papers. Sample sizes are small to moderate,. Alpha-2 agonists are known to be MAC-sparing (Gozalo-Marcilla et al., 2010 and Tokushige et al., 2015), so horses undergoing infusions often have more stable planes of anaesthesia. This can lead to comparatively more frequent administration of rescue top-up doses of ketamine or thiopental in the control groups to maintain a suitable plane of anaesthesia (Marcilla et al., 2012). These drugs are known to have a negative impact on recovery quality as they can cause ataxia, so this could lead to considerable bias for better recoveries in the CRI group. Another point to note when interpreting the evidence is that different PIVA protocols will provide variable levels of analgesia and as most of the study horses were undergoing elective surgery (Devisscher et al. 2010; Marcilla et al., 2012; Schauvliege et al., 2011; and Tokushige et al., 2015) and therefore surgical stimulation, the presence of pain may also have a negative influence on recovery quality in horses not receiving an alpha-2 agonist CRI. The studies where anaesthesia was performed without surgery (Creighton et al., 2012; GozaloMarcilla et al., 2013; Risberg et al., 2016; and Simeonova et al., 2017) may not be very applicable to clinical scenarios as surgical factors are important at influencing recovery from anaesthesia.

Assessing the quality of recovery in horses after general anaesthesia is challenging as scores are often descriptive or subjective as objective measurements are restricted to timing of variables, such as time until sternal recumbency is achieved or number of attempts taken to stand. However, some of these also have a degree of subjectivity such as what constitutes an attempt to stand. Assessment of ataxia is used in many papers, but again is open to interpretation by the observer. All the papers used subjective or descriptive recovery quality scores, with a varying number of observers from one to two. Blinding of the observers was also variable in the studies, which has the potential to introduce significant bias There is no objective way to appraise recovery, and good recovery scores do not always equate to a successful outcome as horses which have a calm and relaxed recovery with minimal attempts to stand can still suffer catastrophic injury; but it is currently regarded as the most appropriate way to quantify the quality of recoveries. The papers all stated that no horses suffered adverse consequences directly related to the recovery period.

Many alpha-2 agonists are used during anaesthetic protocols, although medetomidine and dexmedetomidine are the most commonly used for an infusion for PIVA according to studies. No alpha-2 adrenoceptor agonists are currently licensed in the UK for intravenous infusions and neither medetomidine or dexmedetomidine have a UK Marketing Authorisation for use in horses, therefore need to be used in accordance with the Cascade. The application of the evidence obtained from the papers can easily be applied to clinical practice as the protocols are all easy achievable and are cost effective in real-life scenarios.

After appraising the evidence available, a CRI of an apha- 2 agonist leads to equal ( $3 / 8$ papers) or better (5/8 papers) recovery scores in healthy horses undergoing general anaesthesia, with isoflurane or sevoflurane, compared to those who have received volatile only anaesthesia maintenance. Sacks et al. (2017) directly compared medetomidine and dexmedetomidine infusions and showed dexmedetomidine to be favourable in terms of anaesthetic recovery quality, with no negative effects of using this protocol noted. Further evidence in this area would be beneficial, and by increasing recovery observer numbers, and the number of horses included in the study, the evidence would be of higher quality. The small number of studies performed have 
only included healthy horses undergoing anaesthesia, which may not represent many real-life scenarios of prolonged anaesthesia in sick patients Prolonged administration of alpha-2 agonists may also affect muscle perfusion in horses, which can have significant effects on oxygen delivery and a successful recovery. None of the horses in the alpha-2 CRI groups had evidence of equine post anaesthetic myopathy in any of the papers.

In summary, there is limited high quality evidence to show that the following drugs as a CRI will improve recovery quality when compared to volatile agent only anaesthetic maintenance and recommendations for using a CRI to improve recovery quality would be:

- medetomidine at a bolus of $5-7 \mathrm{mcg} / \mathrm{kg}$, followed by a CRI of $1.75-5 \mathrm{mcg} / \mathrm{kg} /$ hour (Creighton et al., 2012; Simeonova et al., 2017; and Tokushige et al., 2015), or

- dexmedetomidine as a bolus of 3-8 mcg/kg IV followed by a CRI of $1.75 \mathrm{mcg} / \mathrm{kg} / \mathrm{hour}$ (Marcilla et al., 2012; and Risberg et al., 2016)

More evidence is needed to further investigate if there is a beneficial effect of further sedation on recovery after a CRI of an alpha-2 agonist, compared to maintenance of anaesthesia on volatile agents alone in larger populations of horses undergoing surgery in real-life clinical scenarios.

\section{Methodology Section}

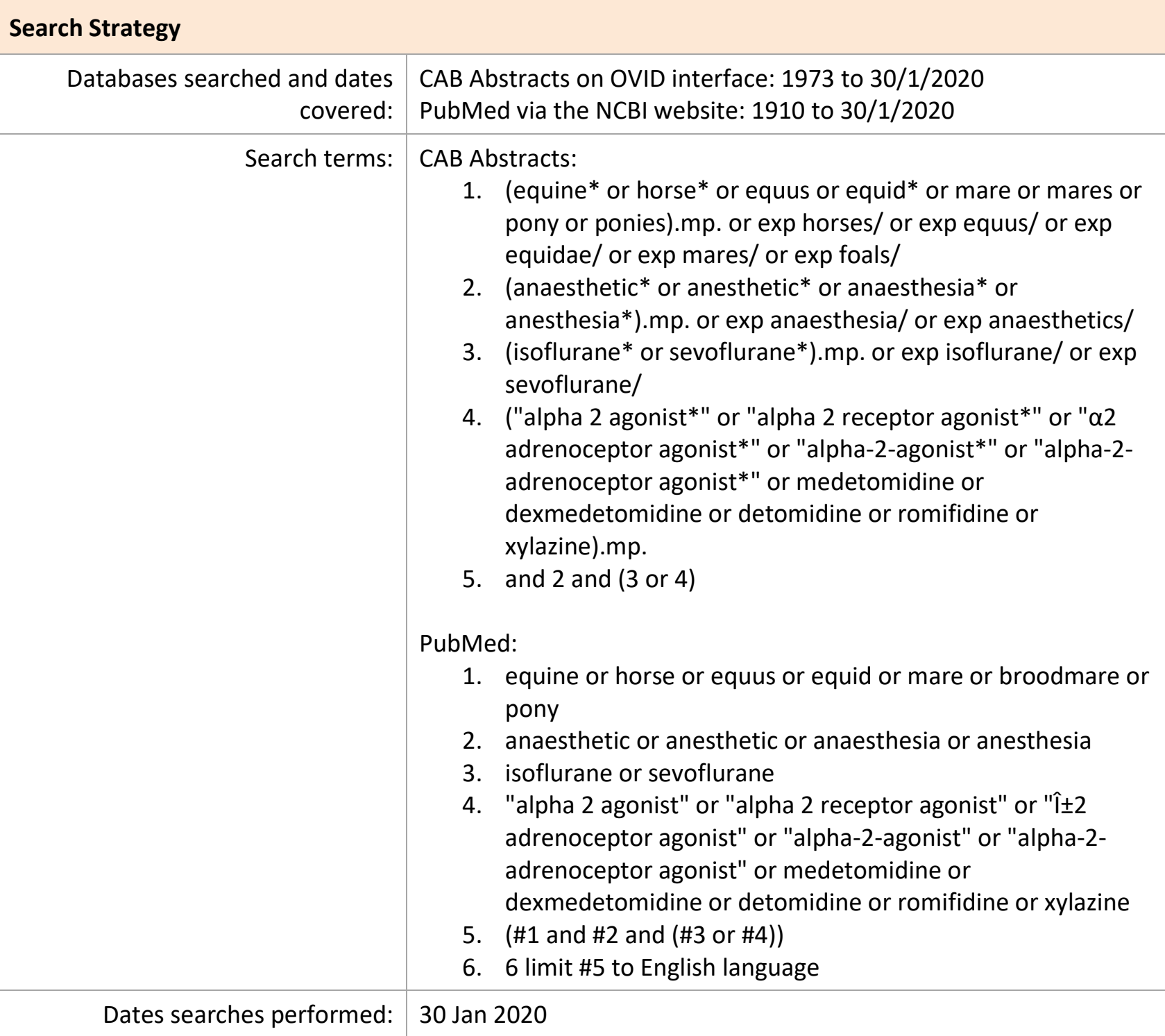




\begin{tabular}{|c|c|c|c|c|c|c|}
\hline \multicolumn{7}{|c|}{ Exclusion / Inclusion Criteria } \\
\hline & \multicolumn{2}{|r|}{ Exclusion: } & \multicolumn{4}{|c|}{$\begin{array}{l}\text { Studies unrelated to the PICO question } \\
\text { Book chapters/reviews or other non-research articles } \\
\text { Publications not in English } \\
\text { Articles where full-text is not available }\end{array}$} \\
\hline & \multicolumn{2}{|r|}{ Inclusion: } & \multicolumn{4}{|c|}{ Studies related to the PICO question in English } \\
\hline \multicolumn{7}{|c|}{ Search Outcome } \\
\hline Database & $\begin{array}{l}\text { Number } \\
\text { of } \\
\text { results }\end{array}$ & $\begin{array}{l}\text { Excluded - } \\
\text { Unrelated } \\
\text { to PICO } \\
\text { question }\end{array}$ & $\begin{array}{l}\text { Excluded - Full } \\
\text { article not } \\
\text { available }\end{array}$ & $\begin{array}{l}\text { Excluded - Not } \\
\text { original research } \\
\text { article }\end{array}$ & $\begin{array}{l}\text { Excluded - Full } \\
\text { text not in } \\
\text { English }\end{array}$ & $\begin{array}{l}\text { Total } \\
\text { relevant } \\
\text { papers }\end{array}$ \\
\hline $\begin{array}{l}\text { CAB } \\
\text { Abstracts }\end{array}$ & 1539 & 951 & 87 & 239 & 256 & 6 \\
\hline PubMed & 753 & 680 & 4 & 48 & 14 & 7 \\
\hline \multicolumn{6}{|c|}{ Total relevant papers when duplicates removed } & 8 \\
\hline
\end{tabular}

\section{CONFLICT OF INTEREST}

The author declares no conflicts of interest.

\section{REFERENCES}

1. Bidwell, L.A., Bramlage, L.R. \& Rood, W.A. (2007). Equine perioperative fatalities associated with general anaesthesia at a private practice--a retrospective case series. Veterinary Anaesthesia and Analgesia. 34(1), 23-30. DOI: http://dx.doi.org/10.1111/j.1467-2995.2005.00283.x

2. Creighton, C.M., Lemke, K.A., Lamont, L.A., Horney, B.S. \& Doyle, A.J. (2012). Comparison of the effects of xylazine bolus versus medetomidine constant rate infusion on the stress response, urine production, and anesthetic recovery characteristics in horses anesthetized with isoflurane. Journal of the American Veterinary Medical Association. 240(8), 998-1002. DOI: http://dx.doi.org/10.2460/javma.240.8.998

3. Devisscher, L., Schauvliege, S., Dewulf, J. \& Gasthuys, F. (2010). Romifidine as a constant rate infusion in isoflurane anaesthetized horses: a clinical study. Veterinary Anaesthesia and Analgesia. 37(5), 425433. DOI: http://dx.doi.org/10.1111/j.1467-2995.2010.00556.x

4. Dugdale, A.H.A., Obhrai, J. \& Cripps, P.J. (2016). Twenty years later: a single-centre, repeat retrospective analysis of equine perioperative mortality and investigation of recovery quality. Veterinary Anaesthesia and Analgesia. 43(2), 171-178.

DOI: http://dx.doi.org/10.1111/vaa.12285 
5. Gozalo-Marcilla, M., Hopster, K., Gasthuys, F., Hatz, L., Krajewski, A.E. \& Schauvliege, S. (2013). Effects of a constant-rate infusion of dexemedtomidine on the minimal alveolar concentration of sevoflurane in ponies. Equine Veterinary Journal. 45(2), 204-208. DOI: https://doi.org/10.1111/j.20423306.2012.00613.x

6. Johnston, G.M., Eastment, J.K., Wood, J.L.N. \& Taylor, P.M. (2002). The confidential enquiry into perioperative equine fatalities (CEPEF): mortality results of phases 1 and 2. Veterinary Anaesthesia and Analgesia. 29(4), 159-170. DOI: http://dx.doi.org/10.1046/i.1467-2995.2002.00106.x

7. Kempchen, S., Kuhn, M., Spadavecchia, C. \& Levionnois, O.L. (2012). Medetomidine continuous rate infusion in horses which surgical anaesthesia is maintained with isoflurane and intravenous infusions of lidocaine and ketamine. Veterinary Anaesthesia and Analgesia. 39(3), 245-255.

DOI: http://dx.doi.org/10.1111/j.1467-2995.2011.00701.x

8. Marcilla, M.G., Schauvliege, S., Duchateau, L. \& Gasthuys, F. (2010). Cardiopulmonary effects of two constant rate infusions of dexmedetomidine in isoflurane anesthetized ponies. Veterinary Anaesthesia and Analgesia. 37(4), 311-321. DOI: https://doi.org/10.1111/j.1467-2995.2010.00537.x

9. Marcilla, M.G., Schauvliege, S., Segaert, S., Duchateau, L. \& Gasthuys, F. (2012). Influence of a constant rate infusion of dexmedetomidine on cardiopulmonary function and recovery quality in isoflurane anaesthetized horses. Veterinary Anaesthesia and Analgesia. 39(1), 49-58.

DOI: http://dx.doi.org/10.1111/i.1467-2995.2011.00672.x

10. Platt, J.P., Simon, B.T., Coleman, M., Martinez, E.A., Lepiz, M.A. \& Watts, A.E. (2017). The effects of multiple anaesthetic episodes on equine recovery quality. Equine Veterinary Journal. 50(1), 111-116. DOI: http://dx.doi.org/10.1111/evj.12728

11. Ringer, S. K., Kalchofner, K., Boller, J. \& Fürst, A. (2007). A clinical comparison of two anaesthetic protocols using lidocaine or medetomidine in horses. Veterinary Anaesthesia and Analgesia. 34(4), 257-268. DOI: http://dx.doi.org/10.1111/j.1467-2995.2006.00321.x

12. Risberg, A.I., Ranheim, B., Krontveit, R.I., Lervik, A. \& Haga, H.A. (2016). The cardiovascular status of isoflurane-anaesthetized horses with and without dexmedetomidine constant rate infusion evaluated at equivalent depths of anaesthesia. Veterinary Anaesthesia and Analgesia. 43(4), 412-423.

DOI: http://dx.doi.org/10.1111/vaa.12315

13. Sacks, M., Ringer, S.K., Bischofberger, A.S., Berchtold, S.M. \& Bettschart-Wolfensberger, R. (2017). Clinical comparison of dexmedetomidine and medetomidine for isoflurane balanced anaesthesia in horses. Veterinary Anaesthesia and Analgesia. 44(5), 1128-1138.

DOI: http://dx.doi.org/10.1016/j.vaa.2016.12.061

14. Santos, M., Fuente, M., Carcia-Iturralde, P., Herran, R., Lopez-Sanroman, J. \& Tendillo, F.J. (2003). Effects of alpha-2 adrenoceptor agonists during recovery from isoflurane anaesthesia in horses. Equine Veterinary Journal. 35(2), 170-175. DOI: http://dx.doi.org/10.2746/042516403776114117

15. Schauvliege, S., Marcilla, M.G., Verryken, K., Duchateau, L., Devisscher, L. \& Gasthuys, F. (2011). Effects of a constant rate infusion of detomidine on cardiovascular function, isoflurane requirements and recovery quality in horses. Veterinary Anaesthesia and Analgesia. 38(6), 544-554.

DOI: http://dx.doi.org/10.1111/i.1467-2995.2011.00659.x

16. Simeonova, G.P., Dinev, D.N. \& Sleiman, M.U. (2017). Comparative Study on Sevoflurane Anesthesia Alone and Combined with Partial Intravenous Anesthesia using Dexmedetomidine in Healthy Horses. Pakistan Veterinary Journal. 37(2), 155-159.

17. Tokushige, H., Ohta, M., Okano, A., Kuroda, T., Kakizaki, M., Ode, H., Aoki, M., Wakuno, A. \& Kawasaki, K. (2015). Effects of Medetomidine Constant Rate Infusion on Sevoflurane Requirement, Cardiopulmonary Function, and Recovery Quality in Thoroughbred Racehorses Undergoing Arthroscopic Surgery. Journal of Equine Veterinary Science. 35(1), 83-87.

DOI: http://dx.doi.org/10.1016/j.jevs.2014.11.004

18. Valverde, A., Rickey, E., Sinclair, M., Rioja, E., Pedernera, J., Hathway, A. \& Cruz, A. (2010). Comparison of cardiovascular function and quality of recovery in isoflurane-anaesthetised horses administered a constant rate infusion of lidocaine or lidocaine and medetomidine during elective surgery. Equine Veterinary Journal. 42(3), 192-199. DOI: https://doi.org/10.1111/j.2042-3306.2010.00027.x 
19. Valverde, A., Black, B., Cribb, N.C., Hathaway, A. \& Daw, A. (2013). Assessment of unassisted recovery from repeated general isoflurane anesthesia in horses following post-anesthetic administration of xylazine or acepromazine or a combination of xylazine and ketamine. Veterinary Anaesthesia and Analgesia. 40(1), 3-12. DOI: https://doi.org/10.1111/i.1467-2995.2012.00782.x

20. Vetoratto, E., Chase-Topping, M.E. \& Clutton, R.E. (2010). A comparison of four systems for scoring recovery quality after general anaesthesia in horses. Equine Veterinary Journal. 42(5), 400-406. DOI: https://doi.org/10.1111/i.2042-3306.2010.00093.x

21. Young, S.S. \& Taylor, P.M. (1993). Factors influencing the outcome of equine anaesthesia: a review of 1,314 cases. Equine Veterinary Journal. 25(2), 147-151. DOI: https://doi.org/10.1111/i.20423306.1993.tb02926.x 


\section{EVIIDEFeE

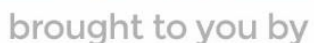 \\ RCVS KNOWLEDGE}

\section{Intellectual Property Rights}

Authors of Knowledge Summaries submitted to RCVS Knowledge for publication will retain copyright in their work, and will be required to grant RCVS Knowledge a non-exclusive license of the rights of copyright in the materials including but not limited to the right to publish, re-

publish, transmit, sell, distribute and otherwise use the materials in all languages and all media throughout the world, and to license or permit others to do so.

\section{Disclaimer}

Knowledge Summaries are a peer-reviewed article type which aims to answer a clinical question based on the best available current evidence. It does not override the responsibility

of the practitioner. Informed decisions should be made by considering such factors as individual clinical expertise and judgement along with patient's circumstances and owners' values. Knowledge Summaries are a resource to help inform and any opinions expressed within the Knowledge Summaries are the author's own and do not necessarily reflect the view of the RCVS Knowledge. Authors are responsible for the accuracy of the content. While the

Editor and Publisher believe that all content herein are in accord with current recommendations and practice at the time of publication, they accept no legal responsibility

for any errors or omissions, and make no warranty, express or implied, with respect to material contained within.

For further information please refer to our Terms of Use.

RCVS Knowledge is the independent charity associated with the Royal College of Veterinary Surgeons (RCVS). Our ambition is to become a global intermediary for evidence based veterinary knowledge by providing access to information

that is of immediate value to practicing veterinary professionals and directly contributes to evidence based clinical decision-making.

https://www.veterinaryevidence.org/

RCVS Knowledge is a registered Charity No. 230886.

Registered as a Company limited by guarantee in England and Wales No. 598443.

Registered Office: Belgravia House, 62-64 Horseferry Road, London SW1P 2AF

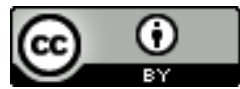

This work is licensed under a Creative Commons Attribution 4.0 International License 